\title{
Three new American species of Munidopsis (Crustacea: Anomura: Munidopsidae)
}

\author{
Gary C. B. Poore
}

Museum Victoria, GPO Box 666, Melbourne, Vic. 3000, Australia. E-mail: gpoore@museum.vic. gov.au

\begin{abstract}
Three new species of Munidopsis (M. amapa and M. brasilia from Brazil, and M. bajacalifornia from California and the Galápagos Islands) are described. All are small, superficially similar to each other and from shallower depths than is typical of most of the genus. All species have a highly sculptured carapace, triangular rostrum and immovable eyestalks with prominent anterior eyespines.
\end{abstract}

Key words: Central-eastern Pacific, Munidopsis, new species, Southwestern Atlantic

Zoobank LSID: urn:Isid:zoobank.org:pub:21D3DD6F-D39D-4821-B058-560D44F60748

Zoobank LSID: urn:Isid:zoobank.org:author:C004D784-E842-42B3-BFD3-317D359F8975

\section{INTRODUCTION}

Collections of squat lobsters in museums in the USA and Brazil were surveyed as a contribution to Museum Victoria's Mapping the World's Oceans project (part of INDEEP, International network for Scientific investigation of deepsea ecosystems http://www.indeep-project.org/ wg/global-biodiversity-biogeography). Several specimens belonging to three new species of Munidopsis were uncovered. Munidopsis comprises more than 230 accepted described species, about two-thirds from the Indo-West Pacific (Baba et al., 2008; WoRMS Editorial Board, 2014). About two-thirds of all species are found at depths below $1000 \mathrm{~m}$ (Baeza, 2011). The three new species are small, superficially similar to each other, and all are from shallower depths that is typical of most of the genus; two are from the Southwestern Atlantic and the other from the Central-eastern Pacific. In this contribution the three species are described. The discussion that follows the descriptions examines their similarities to each other and to other species.

\section{Material and Methods}

Material of two species was collected as part of environmental programs in Brazil: Projeto Habitats Heterogeneidade Ambiental de Bacia de Campos organised by CENPES/PETROBRAS (HAB-11 station); and Programa de Avaliação do Potencial Sustentável de Recursos Vivos da Zona Econômica Exclusiva (REVIZEE station). These are now housed in the Museu Nacional Rio de Janeiro (MNRJ) and Museu de Zoologia, UniversidadedeSão Paulo(MZUSP). Specimens of the third species were collected by the Allan Hancock Foundation vessel Velero III and is now housed in the Natural History Museum of Los Angeles County (LACM), California Academy of Sciences, San Francisco (CAS), and Smithsonian Institution National Museum of Natural History, Washington (USNM).

Counts of spines are given as $\mathrm{x}+1$ where +1 indicates a distal marginal spine. Sizes are given as total length, including rostrum (tl.). Photographs were made using a Leica M205C microscope and the multifocus function in the Leica Application Suite 3.8.0. 


\section{Results}

Munidopsidae Ortmann, 1898

Munidopsis Whiteaves, 1874

Remarks: The genus is separated from other squat lobsters by the combination of absence of flagellum on maxilliped 1 exopod, maxilliped 3 with epipod well developed, no middorsal carapace spines and reduced eyes (Macpherson and Baba, 2011).

Munidopsis amapa sp. nov.

Zoobank LSID: urn:lsid:zoobank. org:act:E8CCEBB3-AEB1-4B40-B499-

\section{DE32DFE8C84}

(Figs. 1a, 2)

Material examined. Holotype. Brazil. Off Amapá, 322’ N, 4850.5’W, 101 m, 13 Sep 1970 (Almirante Sandanha stn G125), MNRJ 8879 (male, tl. $5.2 \mathrm{~mm}$, without pereopods). Paratype. Collected with holotype, MZUSP 31582 (ovigerous female, tl. $4.7 \mathrm{~mm}$, without pereopods).

Diagnosis: Carapace 1.35 times as long as wide (rostrum included), surface sparsely setose, coarsely squamate over major tubercles, each variously anteriorly obliquely directed. Rostrum triangular, shorter than basal width, slightly upturned, with median row of denticles, 0.26 total carapace length, 0.43 distance between anterolateral angles; distal half with margins straight, proximal half concave with constriction between. Carapace: gastric region prominently raised, with anterior median tubercle plus 5 transverse rows of tubercles, first of 3 pairs (submedian epigastric larger than more lateral), second of 3 pairs (middle one larger than submedian and lateral), third of 2 pairs (submedian widely separated from lateral), fourth of 2 pairs (lateral more anterior than posterior), and fifth of 1 pair; hepatic region with prominent squamate shoulder overhanging anterolateral margin, otherwise irregularly squamose; cardiac region prominent behind a wide shallow transverse groove marked anteriorly by a row of postcervial tubercles, with 2 pairs of submedian tubercles and 1 smaller lateral pair; anterior branchial region irregularly tuberculate; posterior branchial region 7 or 8 tubercles more or less arranged in 3 oblique rows; cervical groove shallow and sharp in middorsal; posterior margin tuberculate. Abdominal tergites 2-4 squamose, with 2 low ridges separated by shallow median shaped groove; pleuron 2 broadly rounded, 3 and 4 narrowly rounded, ridged. Eyestalks immovable, with truncate denticulate distomesial margin adpressed to rostrum, and prominent blunt ventrolateral and dorsolateral projections. Antennular article 1 with upper and lower distolateral spines. Pereopods 1-3 with epipod.

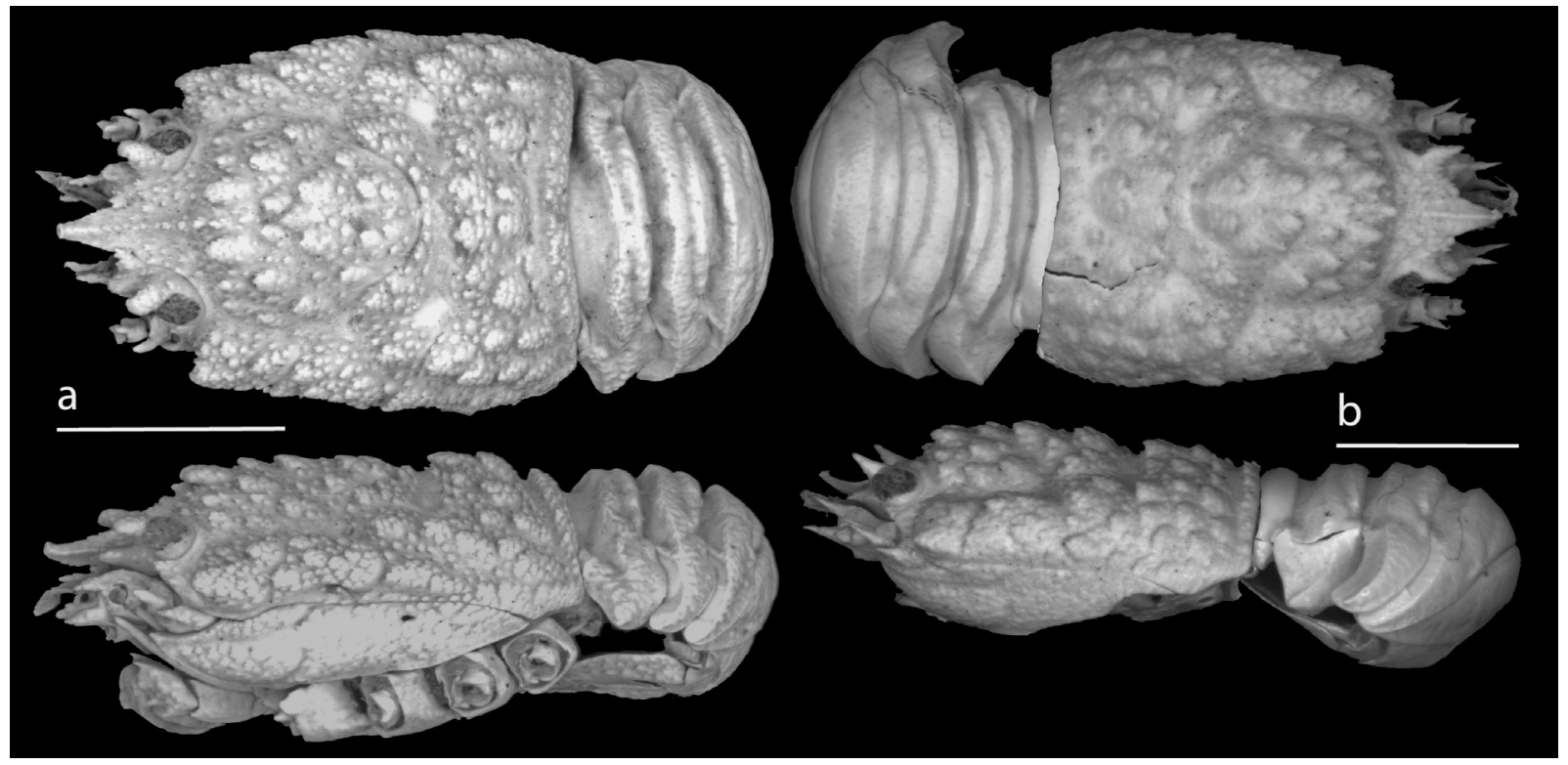

Figure 1. Dorsal and lateral views of holotypes of new species of Munidopsis. (a) M. amapa holotype. (b) M. bajacalifornia holotype. Scale bars are $1 \mathrm{~mm}$. 


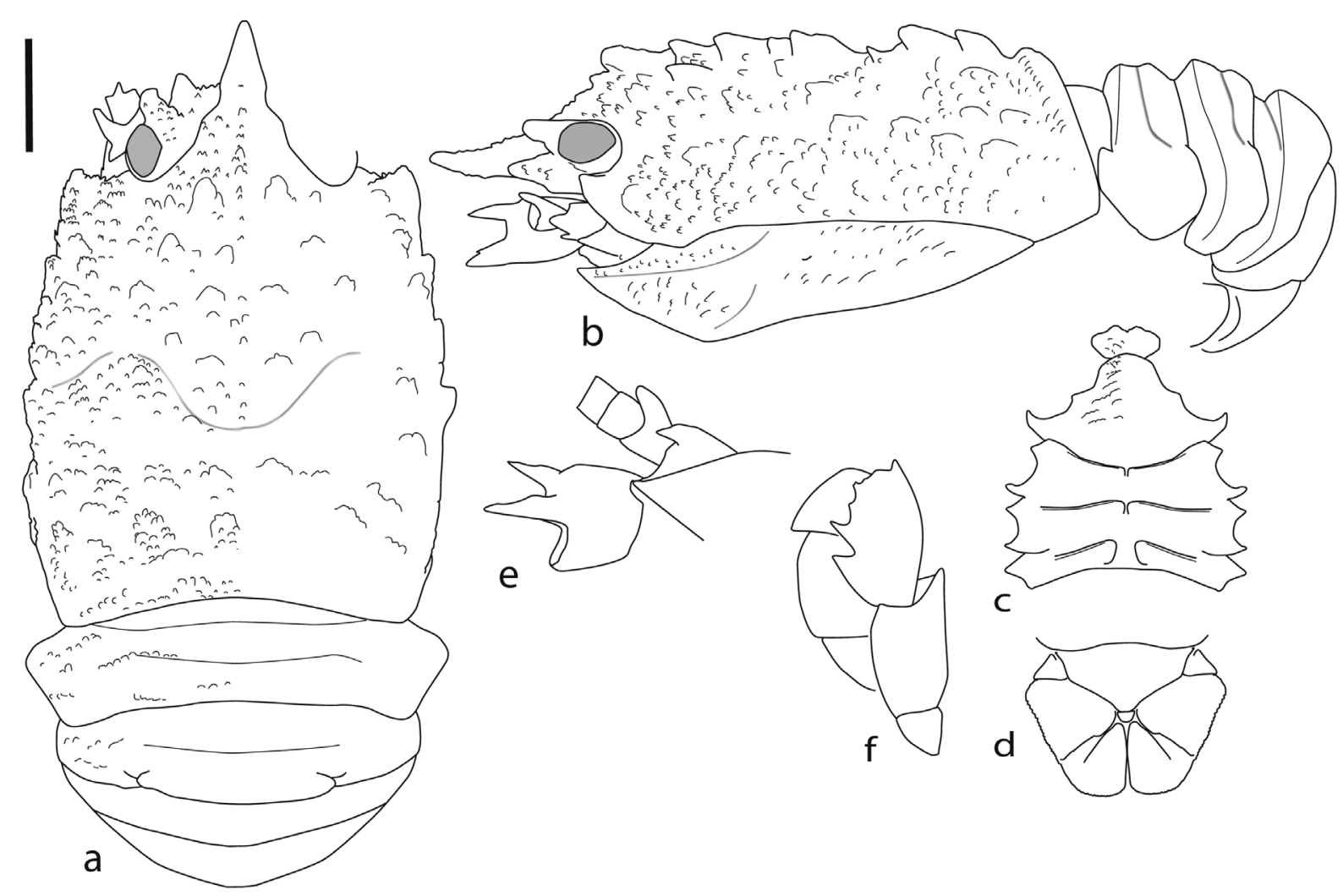

Figure 2. Munidopsis amapa sp. nov., holotype. (a, b) dorsal view of carapace and abdomen (tubercles on left side only shown). (c) sternites 3-7. (d) telson. (e) oblique ventral view of branchiostegal spine, peduncular article 1 of left antennule and peduncular articles 1-4 of left antenna. (f) maxilliped 3. Scale bar = $1 \mathrm{~mm}$ (habitus, sternum and telson).

Description: Carapace and rostrum ornamented as diagnosed above. Anterolateral margin transverse; anterolateral angle rounded (not visible in dorsal view); outer orbital angle rightangled, sharp, margins serrated. Lateral margins convex, anterior width 0.8 greatest width. Pterygostomian region squamate, anterior angle acute.

Sternum as long as greatest width at sternite 7. Sternite 30.35 width of sternite 4; anterior margin irregularly dentate, deeply emarginate between 2 submedial lobes; posterolateral margins rounded. Sternite 4 anterior margin prominently produced as broad lobe, convex between anterolateral corners; surface with scattered setose striae. Sternites 5-7 smooth.

Abdomen integument squamose; tergites 2-4, with 2 low ridges separated by shallow median shaped groove; pleuron 2 broadly rounded, 3 and 4 narrowly rounded, ridged; somites 5, 6 smooth. Telson 1.4 times as wide as long, widest at 0.3 length; composed of 8 well separated plates; margins setose. Uropodal endopod squamose; margins setose.
Eyestalk immovable, with truncate denticulate distomesial margin adpressed along two-thirds of side of rostrum, and prominent blunt ventrolateral and dorsolateral projections reaching little more than half rostrum length. Cornea hemispherical, lateral, occupying proximal half of eyestalk.

Antennule article 1 barrel-like, with upper and lower distolateral spines.

Antenna article 1 with blunt lateral tooth, shorter than article 2; article 2 with 1 blunt distodorsal spine; articles 3-5 unarmed.

Maxilliped 3 ischium margins unarmed; crista dentata with c. 30 corneous teeth; merus extensor margin unarmed, flexor margin with 2 prominent teeth and 2 obsolete, extensor margin with 1 distal tooth; carpus-dactylus unarmed.

Pereopods 1-3 with epipod. Distribution: Northern Brazil, $101 \mathrm{~m}$ depth. Etymology: From Amapá, the state of Brazil close to the type locality, noun in apposition. Remarks: The maximum total length recorded is $5.2 \mathrm{~mm}$ as is the case for all three species. 

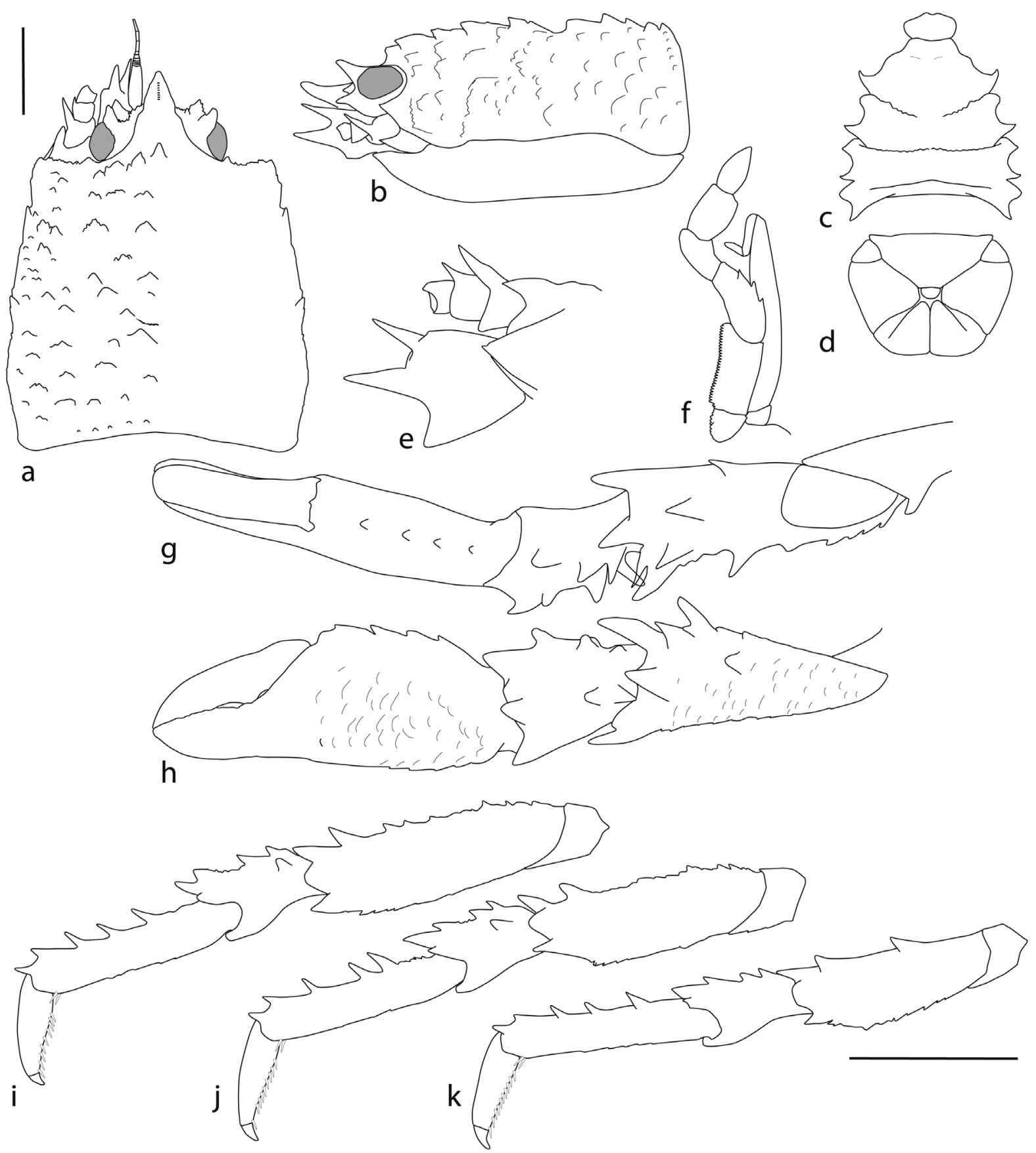

Figure 3. Munidopsis bajacalifornia sp. nov., holotype. (a, b) dorsal and lateral views of carapace (only major tubercles on left side shown). (c) sternites 3-7. (d) telson. (e) oblique ventral view of branchiostegal spine, peduncular article 1 of left antennule and peduncular articles 1-4 of left antenna. (f) maxilliped 3. (g, h) upper and lateral views of left pereopod 1 (cheliped). (i-k) left pereopods 2-4. Scale bars $=1 \mathrm{~mm}$, upper left for carapace, sternum, telson, lower right for pereopods $1-4$.

Neither of the types possesses pereopods but these are assumed to be similar to those of the next species, $M$. bajacalifornia with which it is compared below.

Munidopsis bajacalifornia sp. nov.

Zoobank LSID: urn:lsid:zoobank.

org:act:1AB7402A-9082-45E6-9662-

CB18FBCB6781

(Figs. 1b, 3)
Material examined. Holotype. Mexico. Off San Benito Is, Baja California, 28 $8^{\circ} 12.05, \mathrm{~N}$, $115^{\circ} 33.33^{\prime} \mathrm{W}$ to $28^{\circ} 12.67^{\prime} \mathrm{N}, 115^{\circ} 33.75^{\prime} \mathrm{W}$, 130-174 m, fine green sand, 20 Sep 1939 (Velero III stn 1010-39), LACM CR 1939-188 (female, tl. $4.4 \mathrm{~mm}$ ).

Paratypes. Mexico. $1.5 \mathrm{mi}(2.4 \mathrm{~km})$ off $\mathrm{N}$ end of Cedros I., Baja California, 28 23.33'N, $115^{\circ} 11.90^{\prime} \mathrm{W}, 101-110 \mathrm{~m}$, shale, pebbles, 28 
Feb 1941 (Velero III stn 1264-41), LACM (2 fragmented males, tl. 5.2, $4.8 \mathrm{~mm}$ ). Puerto Escondido, off Carmen I., Baja California, $25^{\circ} 51.83^{\prime} \mathrm{N}, 111^{\circ} 15.67^{\prime} \mathrm{W}, 110 \mathrm{~m}$, mud, 12 Mar 1937 (Velero III stn 667-37), USNM 1188680 (male, tl. $4.6 \mathrm{~mm}$ ). Ecuador, Galápagos Islands, Isla Beagle, 0425's, 90³7’W, coll. Angermeyer, 1969, CAS-IZ 190361 (male, tl. $3.6 \mathrm{~mm}$ ).

Diagnosis: Carapace 1.6 times as long as wide (rostrum included), surface sparsely setose, coarsely squamate over major tubercles, each variously anteriorly obliquely directed. Rostrum triangular, as wide as long, upturned, with median ridge, length 0.23 total carapace length, 0.6 distance between anterolateral angles; distal half with margins straight, proximal half concave with constriction between. Carapace: gastric region prominently raised, with anterior median tubercle plus 4 transverse rows of tubercles, first of 3 pairs (submedian epigastric larger than more lateral), second of 3 similar pairs evenly spaced, third of 2 pairs (submedian widely separated from lateral), and fourth of 2 pairs (lateral more anterior than posterior); hepatic region with prominent squamate shoulder overhanging anterolateral margin, otherwise irregularly squamose; cardiac region prominent, with 2 pairs of submedian tubercles and 1 smaller lateral pair; anterior branchial region each with 3 larger tubercles dorsally and several smaller laterally; posterior branchial region with low tubercles along cervical groove, a triangular group of tubercles anterolaterally and 3 transverse rows of 3-4 tubercles; cervical groove deep in middorsal; posterior margin with 6 pairs of tubercles, diminishing laterally. Abdominal tergites 2-4 with 2 low ridges separated by shallow median transverse groove; pleuron 2 broadly triangular, ridged; pleura 3 and 4 narrowly triangular, curving forwards ventrally, ridged. Eyestalks immovable, with prominent distomesial spine adpressed to rostrum, and prominent conical ventrolateral and dorsolateral spines. Antennular article 1 with sharp ventrolateral and dorsolateral spines. Chelipeds, equal, 1.4 times carapace length; squamate and spinose. Pereopods 1-3 with epipod.
Description: Carapace and rostrum ornamented as diagnosed above. Anterolateral margin oblique; anterolateral angle rounded (not visible in dorsal view); outer orbital angle right-angled, sharp, margins serrated. Lateral margins convex, anterior width 0.75 greatest width. Pterygostomian region squamate, anterior angle rounded.

Sternum length 0.9 times greatest width at sternite 7 . Sternite 3 about 0.4 width of sternite 4; anterior margin irregularly dentate, scarcely emarginate medially; posterolateral margins rounded. Sternite 4 anterior margin prominently produced as trapezoid lobe, concave between rounded anterolateral corners; surface obscurely rugose. Sternites 5-7 smooth.

Abdomen integument irregularly dimpled; tergites 2-4 with 2 low ridges separated by shallow median transverse groove; pleuron 2 broadly triangular, with transverse ridge curving anteroventrally; pleura 3 and 4 narrowly triangular, each with transverse ridge curving anteroventrally; somites 5, 6 smooth. Telson 1.3 times as wide as long, widest at 0.3 length; composed of 8 well separated plates; margins setose. Uropodal endopod unarmed; margins setose.

Eyestalk immovable, sparsely setose, with prominent distomesial lobe adpressed along two-thirds of side of rostrum, denticulate laterally; with strong oblique conical distodorsal and shorter distoventral projections reaching little more than half rostrum length. Cornea hemispherical, lateral, occupying proximal two-thirds of eyestalk.

Antennule article 1 swollen, with obsolete distomesial spine, distoventral spine about as long as body of article and shorter distodorsal process.

Antenna article 1 with short sharp lateral tooth; article 2 with lateral spine reaching distal margin of article 3; article 3 with short lateral spine; article 4 unarmed.

Maxilliped 3 ischium extensor margin with c. 30 low teeth, flexor margin unarmed; crista dentata with c. 30 corneous teeth; merus extensor margin unarmed, flexor margin with 3 low teeth; carpus-dactylus unarmed. 
Pereopods 1 (cheliped) of female equal, 1.4 times carapace length; surfaces rugose, densely covered with raised squamae; merus twice as long as carpus, upper edge with $2+1$ mesial, $1+1$ in midline and $1+1$ (fine) lateral spines, lateral face with $1+1$ spines; lower margin with 1 distal spine; carpus upper edge with proximal bifid tooth and $1+1$ in midline, lateral face with $1+1$ teeth, lower margin with 2 proximal spines; propodal palm 1.2 times as long as dactylus, length 2.6 times height, upper edge with 4 obsolete teeth; fixed finger with sharp blade-like outer margin, notched proximally, with 3 sharp obtuse distal teeth, mesial margin rounded, upper surface concave; dactylus with sharp blade-like outer margin, with rounded proximal tooth, with semicircular apex shorter than fixed finger, mesial margin rounded.

Pereopods 2-4 similar, surfaces squamose, decreasing in length posteriorly. Pereopod 2 not overreaching cheliped carpus; merus extensor margin with 9 irregular teeth, 1 stronger subdistal tooth and 1 distal spine, 1 distal spine on flexor margin; carpus extensor margin with 4 teeth in blade-like ridge plus 1 proximal tooth on upper lateral face; propodus about 5 times as long as high, flexor margin with 4 erect spines plus 1 distal spine, with pair of setae at base of dactylus; dactylus about half propodus length, flexor margin with 8 robust setae and corneous unguis. Pereopod 3 similar to pereopod 2 but teeth on merus less defined. Pereopod 4 similar to pereopod 3 but more compact, merus extensor margin with $2+1$ teeth, propodus extensor margin with $2+1$ plus 1 distal teeth, dactylus with 9 robust setae.

Pereopods 1-3 with epipod.

Distribution: Baja California, Mexico, and Galapagos Islands, Ecuador, $28^{\circ} \mathrm{N}-04^{\circ} \mathrm{S}$, 101-174 m depth.

Etymology: From Baja California, a state of Mexico, for the type locality; noun in apposition.

Remarks: This like the others is a small species, $5.2 \mathrm{~mm}$ being the maximum total length recorded. The combination of squamose teeth on the carapace and acute lateral eyespines on an immovable eyestalk distinguish it from
A. amapa, which has more complex dorsal ornamentation and shorter more rounded lateral eyespines.

Munidopsis brasilia sp. nov.

Zoobank LSID: urn:lsid:zoobank. org:act:0172CA40-5D4B-4A9A-90D9EC92C3E0348F

(Fig. 4)

Material examined. Holotype. Brazil. Off Rio Doce, Espirito Santo, 19³0.99'S, 3846.04'W, 65 m, 28 Jun 2001 (REVIZEE stn 25), MNRJ 16582 (male, tl. $5.2 \mathrm{~mm}$ ).

Paratypes. Brazil. Off Baía do Oiapoque, $04^{\circ} 52^{\prime} \mathrm{N}, 50^{\circ} 31^{\prime} \mathrm{W}, 118 \mathrm{~m}$, (GEOMAR III stn GM208), MZUSP 17187 (male, tl. 3.9 mm, without abdomen, pereopods). OffTamandaré, Pernambuco, c. $9^{\circ} \mathrm{S}, 35^{\circ} \mathrm{W}$, MZUSP 8961 (male, tl. $3.5 \mathrm{~mm}$, without pereopods). Off Cabo de São Tomé, Rio de Janeiro, 2204.16'S, 4007.08'W, 92 m, (HAB-11 stn G04), MNRJ 1230 (male, tl. $4.8 \mathrm{~mm}$, without pereopods). Diagnosis: Carapace 1.2 times as long as wide (rostrum included), surface sparsely setose, generally smooth between major tooth-like tubercles, each anteriorly obliquely directed. Rostrum triangular, shorter than basal width, horizontal, with slight median ridge and pair of marginal teeth on upper face at midlength, 0.24 total carapace length. Carapace: gastric region prominently raised, with anterior median tubercle, 5 transverse rows of tubercles, first of 2 pairs (submedian epigastric larger than more lateral), second of 3 similar pairs evenly spaced, third of 2 pairs (submedian widely separated from more anterior and lateral), fourth of 1 pair, fifth of 1 pair, plus posterior median tubercle; hepatic region with prominent shoulder overhanging anterolateral margin, with 3 prominent lateral teeth, 3 along gastric margin, and 2 intermediate; cardiac region prominent, with 2 pairs of submedian tubercles; anterior branchial region with 2 prominent lateral teeth, 3 smaller dorsal ones; posterior branchial region with low tubercles more or less in 2 transverse rows of 4 or 5; cervical groove shallow in middorsal; posterior margin with 5 pairs of anteriorly 


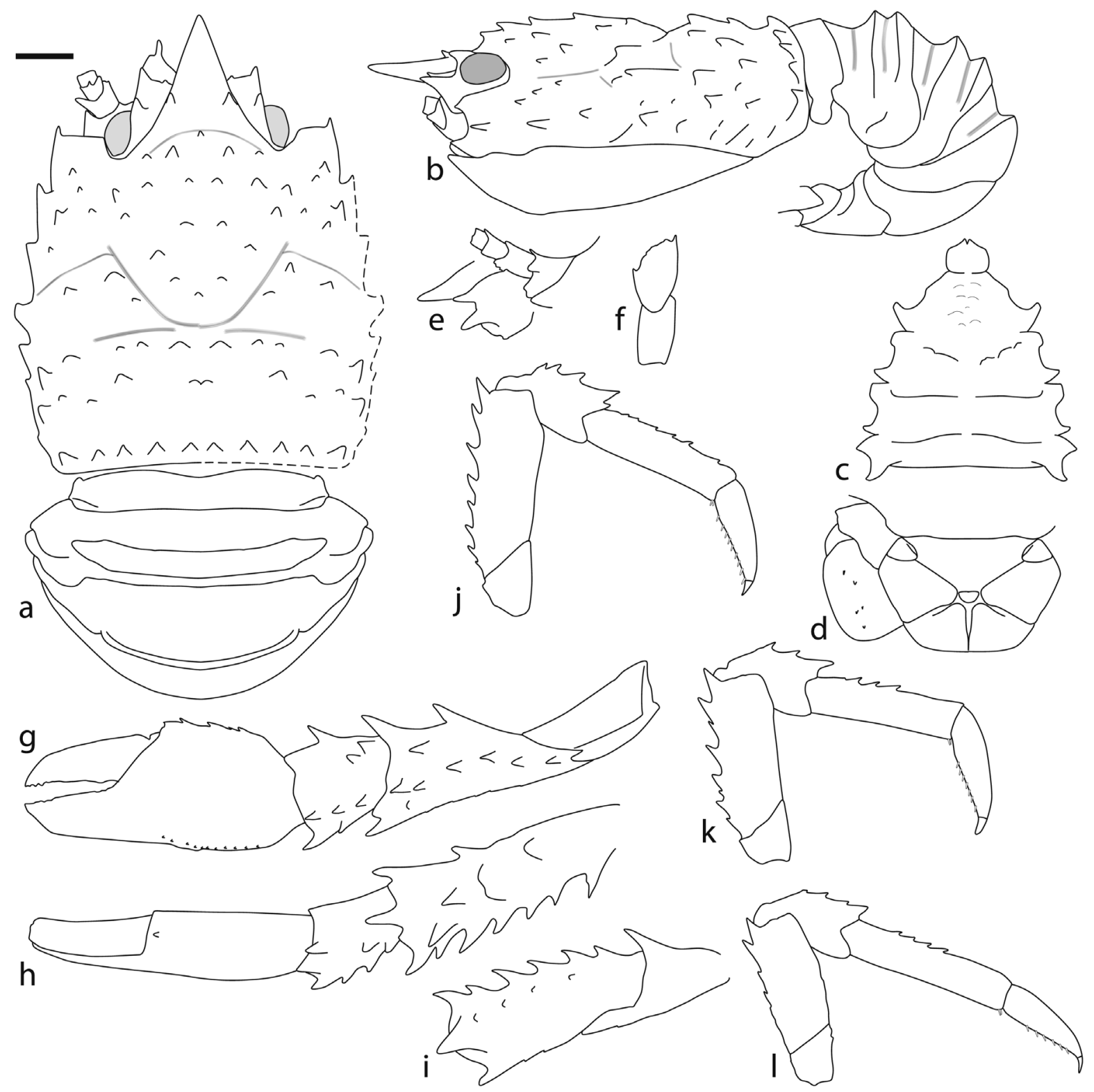

Figure 4. Munidopsis brasilia sp. nov., holotype. a, b, dorsal and lateral view of carapace and abdomen (carapace distorted on right). c, sternites 3-7. d, telson. e, branchiostegal spine, peduncular article 1 of left antennule, peduncular articles 1-4 of left antenna, and rostrum, oblique ventral view. f, maxilliped 3, ischium and merus. g, h, left pereopod 1 (cheliped), upper and mesial views. i, left pereopod 1, lower-lateral view of ischium and merus. $\mathrm{j}-1$, left pereopods $2-4$. Scale bar $=1 \mathrm{~mm}$ (habitus, sternum, telson and pereopods).

directed teeth. Abdominal tergites 2-4 with 2 low ridges separated by median transverse V-shaped groove; pleura $2-4$ broadly rounded, ridged. Eyestalks immovable, deeper than wide, with short blunt dorsolateral spine, and short conical ventrolateral and ventromesial teeth on lower distal margin. Antennular article 1 with distolateral and subdistal mesial spine. Chelipeds, equal, 1.1 times carapace length; squamate and spinose. Pereopods 1-3 with epipod.

Description: Carapace and rostrum ornamented as diagnosed above. Anterolateral margin transverse; anterolateral angle with short, blunt tooth; outer orbital angle blunt, margins straight. Lateral margins barely convex, anterior width 0.6 greatest width. Pterygostomian region squamate, anterior angle acute.

Sternum length 0.9 times greatest width at sternite 7 . Sternite 3 about 0.3 width of sternite 4, anterior margin produced medially, with medial notch; lateral margin convex. Sternite 4 anterior margin prominently produced as trapezoid lobe, straight between 
anterolateral angles; surface with scattered setose striae. Sternites 5-7 with low rugosities.

Abdomen integument irregularly dimpled. Abdominal tergites 2-4 with 2 low ridges separated by median transverse V-shaped groove; pleura 2-4 broadly rounded, ridged; somites 5, 6 smooth. Telson 1.6 times as wide as long, widest at half length; composed of 8 well separated plates; margins setose. Uropodal endopod with few small surficial spines; margins setose.

Eyestalk immovable, deeper than wide, with short blunt dorsolateral spine, and short conical ventrolateral and ventromesial teeth on lower distal margin.

Antennular article 1 with distolateral and subdistal mesial spine. Cornea hemispherical, lateral, occupying proximal half of eyestalk.

Antennule article 1 swollen, with distolateral and subdistal mesial spines shorter than body of article, plus minute mesial tooth.

Antenna articles 1-3 each with blunt lateral tooth; article 2 with denticulate mesial tooth; articles 4, 5 unarmed.

Maxilliped 3 ischium unarmed; merus with small distal teeth; carpus-dactylus unarmed.

Pereopod 1 (cheliped) equal, 1.1 times carapace length; surfaces largely smooth; merus 3 times as long as carpus, upper edge with $1+1$ mesial, $1+1$ in midline, 1 intermediate and $6+1$ lateral spines, lateral face with distal spine; lower margin unarmed; carpus upper edge with 2 proximal +1 blunt teeth, lateral face with $3+1$ teeth, lower margin with 1 spine; propodal palm as long as dactylus, length 2.3 times height, upper edge with 4 irregular teeth, lower margin squamose; fixed finger with sharp blade-like irregular outer margin, with irregular sharp obtuse distal teeth, mesial margin rounded, upper surface concave; dactylus with sharp blade-like outer margin, with semicircular apex about as long as fixed finger, mesial margin rounded.

Pereopods 2-4 similar, surfaces squamose, decreasing in length posteriorly. Pereopod 2 not overreaching cheliped carpus; merus extensor margin with 7 teeth and 1 distal spine; carpus extensor margin with 4 teeth; propodus about 3.5 times as long as high, extensor margin with
7 irregular teeth, with pair of setae at base of dactylus; dactylus 0.8 propodus length, flexor margin with 9 robust setae and corneous unguis. Pereopods 3 and 4 similar to pereopod 2 but teeth on merus fewer, propodus of pereopod 4 longer and narrower.

Pereopods 1-3 with epipod.

Distribution: Northern to central Brazil, $4^{\circ} \mathrm{N}-$ $22^{\circ} \mathrm{S}, 65-118 \mathrm{~m}$ depth.

Etymology: From Brasilia (Latinised spelling of Brazil), reflecting the species' distribution, noun in apposition.

Remarks: This is a small species, $5 \mathrm{~mm}$ being the maximum total length recorded. The combination of well-spaced blunt but definite teeth on the carapace and lateral eyespines on an immovable eyestalk are diagnostic.

\section{DisCUSSION}

Munidopsis is a genus with six junior synonyms that reflect its morphological diversity. A generic revision using morphological and molecular data is underway (S. Ahyong, J. Taylor, N. Andreakis, pers. comm.) so it would be presumptuous to pre-empt this and place the new species in any genus other than Munidopsis. Nevertheless, a superficial review of the type species of these junior synonyms does not reveal a stand-out existing genus name in which to place the new species.

The three species, all from inner- or mid-shelf depths, have in common small size (none much more than $5 \mathrm{~mm}$ long), broad triangular rostrum, eyestalk immovable, with distal eyespines, ornamented dorsal sculpture, and epipods on pereopods 1-3. Twenty-seven species of Munidopsis were listed from the Eastern Pacific by Hendrickx and Harvey (1999), with more recent additions from the Gulf of California (Ayón-Parente and Hendrickx, 2007; Hendrickx, 2007; Hendrickx and Ayón-Parente, 2013). Studies of the fauna of the Gulf of Mexico are relevant to the Brazilian fauna (Pequegnat and Pequegnat, 1970; Pequegnat and Williams, 1995; Váquez-Bader et al., 2014) but only two species of Munidopsis have been reported from Brazil itself (Melo, 1999). All the species 
covered in these studies are from outer shelf or bathyal depths; none is similar to the new species described here.

Munidopsis bajacalifornia and M. amapa are more similar to each other than they are to $M$. brasilia. Both share complex dorsal tubercles on the carapace (notably a stout pair of epigastric tubercles and a pair of protruding hepatic shoulders overlapping the anterolateral carapace margin), a lateral rostral constriction, a prominent anterior lobe on sternite 4, two lateral projections on the eyestalks arranged one above the other, and two lateral spines on article 1 of the antennule. Pereopods are known only for the first of these two. The eyespines on $M$. amapa are more blunt and the rostrum longer and more horizontal than in M. bajacalifornia.

Munidopsis brasilia has dorsal carapace spines rather than complex squamae but shares two lateral eyespines, one above the other, and a spinose merus and carpus on pereopod 1 with the other two species. Sternite 3 is narrower than in the other two species.

In Baba's (2005) key to the Indo-West Pacific species, all fall close to $M$. cascadia Ambler, 1980, $M$. lentigo Williams \& van Dover, 1983 or M. laciniosa Baba, 2005. These are at best superficially similar to the new species. The strongly rugose dorsum densely covered with tubercles or squamae resembles that in other Indo-West Pacific species: Munidopsis bractea Ahyong, 2007, M. papanui Schnabel \& Bruce, 2006, $M$. proales Ahyong \& Poore, 2004, M. tasmaniae Ahyong \& Poore, 2004, M. sonne Baba, 1995, M. taurulus Ortmann, 1892, and M. tuberosa Osawa, Lin \& Chan, 2008. Only M. laciniosa has two vertically aligned eyespines but it is an exceptionally spiny species.

Listing just the most obvious differences of described species from these new American ones, Munidopsis bractea, M. papanui, $M$. taurulus and $M$. tuberosa have more prominent ridges on the abdominal somites and complex antennular spines, $M$. tasmaniae has more prominent lateral hepatic and anterior branchial tubercles, and $M$. proales, $M$. tasmaniae, $M$. sonne and $M$. tuberosa lack prominent eyespines and are less sculptured. Whether or not these three species form a natural group within Munidopsis sensu lato remains to be seen.

ACKNOWLEDGEMENTS - I thank the following individuals and institutions for access to the collections and loans: Regina Wetzer and Adam Hall, Natural History Museum of Los Angeles County; Christina Piotrowski, California Academy of Sciences, San Francisco; Karen Reed, Smithsonian Institution National Museum of Natural History; Cristiana Serejo, Museu Nacional Rio de Janeiro; and Marcos Tavares, Museu de Zoologia, Universidade de São Paulo. Joanne Taylor and Shane Ahyong provided valuable commentary on the species descriptions.

\section{REFERENCES}

Ahyong, S.T. 2007. Decapod Crustacea collected by the NORFANZ Expedition: Galatheidae and Polychelidae. Zootaxa, 1593: 1-54.

Ahyong, S.T. and Poore, G.C.B. 2004. Deep-water Galatheidae (Crustacea: Decapoda: Anomura) from southern and eastern Australia. Zootaxa, 472: 1-76.

Ahyong, S.T.; Baba, K.; Macpherson, E. and Poore, G.C.B. 2010. A new classification of the Galatheoidea (Crustacea: Decapoda: Anomura). Zootaxa, 2676: 57-68.

Ambler, J.W. 1980. Species of Munidopsis (Crustacea, Galatheidae) ocurring off Oregon and in adjacent waters. Fishery Bulletin, 78: 13-34.

Ayón-Parente, M. and Hendrickx, M.E. 2007. New records of crustaceans (Isopoda and Decapoda) along the Pacific coast of Mexico. p. 59-61. In: M.E. Hendrickx (ed.) Contributions to the Study of East Pacific Crustaceans [Contribuciones al Estudio de los Crustáceos del Pacífico Este]. Mazatlán, Instituto de Ciências del Mar y Limnología, UNAM.

Baba, K. 1995. A new squat lobster (Decapoda: Anomura: Galatheidae) from an active thermal vent area in the North Fiji Basin, SW Pacific. Crustacean Research, 24: 188-193.

Baba, K. 2005. Deep-sea chirostylid and galatheid crustaceans (Decapoda: Anomura) from the IndoWest Pacific, with a list of species. Galathea Report, 20: 1-317.

Baba, K.; Macpherson, E.; Poore, G.C.B.; Ahyong, S.T.; Bermudez, A.; Cabezas, P.; Lin, C.-W.; Nizinski, M.; Rodrigues, C. and Schnabel, K.E. 2008. Catalogue of squat lobsters of the world (Crustacea: Decapoda: Anomura - families Chirostylidae, Galatheidae and Kiwaidae). Zootaxa, 1905: 1-220

Baeza, J.A. 2011. Squat lobsters as symbionts and in chemo-autotrophic environments. Chapter 8, p. 249-270 In: G.C.B. Poore, S.T. Ahyong and J. Taylor (eds), The biology of squat lobsters. Melbourne, CSIRO Publishing (also published as Crustacean Issues Vol. 20 by CRC Press: Baton Roca).

Hendrickx, M.E. 2007. Specimens of Munidopsis (Decapoda, Anomura, Galatheidae) collected by the R/V "Revelle" (May 2004) in the Gulf of California, Mexico. Crustaceana, 80: 597-601.

Hendrickx, M.E. and Harvey, A.W. 1999. Checklist of 
anomuran crabs (Crustacea: Decapoda) from the eastern tropical Pacific. Belgian Journal of Zoology, 129: 363-389.

Hendrickx, M.E. and Ayón-Parente, M. 2013. A new species of Munidopsis (Crustacea: Anomura: Galatheoidea: Munidopsidae) from the Gulf of California, western Mexico. Crustaceana, 86: 13061317.

Macpherson, E. and Baba, K. 2011. Chapter 2. Taxonomy of squat lobsters. Chapter 2, p. 39-71. In: G.C.B. Poore, S.T. Ahyong and J. Taylor (eds), The biology of squat lobsters. Melbourne, CSIRO Publishing (also published as Crustacean Issues Vol. 20 by CRC Press: Baton Roca).

Melo, G.A.S. 1999. Manual de identificação dos Crustacea Decapoda do litoral Brasileiro: Anomura, Thalassinidea, Palinuridea, Astacidea. São Paulo, Editora Plêiade/FAPESP, 551 p.

Ortmann, A.E. 1892. Die Decapoden-Krebse des Strassburger Museums, mit besonderer Berücksichtigung der von Herrn Dr. Döderlein bei Japan und bei den Liu-Kiu-Inseln gesammelten und zur Zeit im Strassburger Museum aufbewahrten Formen. IV. Die Abtheilungen Galatheidea und Paguridea. Zoologische Jahrbücher, Abtheilung für Systematik, Geographie und Biologie der Thiere, 6: 241-326.

Ortmann, A.E. 1898-1901. Crustacea (Zweite Hälfte: Malacostraca). p. viii + 1319 (1057-), pls 1128. In: A. Gerstaecker (ed.), Die Klassen und Ordnungen der Arthropoden ... Vol 5 (2) of H.G. Bronn's Die Klassen und Ordnungen der Thier-Reichs wissenschaftlich dargestellt in Wort und Bild. Leipzig, C.F. Winter'sche Verlagshandlung.

Osawa, M.; Lin, C.-W. and Chan, T.-Y. 2008. Species of Galacantha and Munidopsis (Crustacea: Decapoda: Anomura: Galatheidae) from the deep-waters off Taiwan, with the description of two new species. Scientia Marina, 72: 35-57.

Pequegnat, L.H. and Pequegnat, W.E. 1970. Deepsea anomurans of superfamily Galatheoidea with description of three new species. p. 125-170. In: W.E. Pequegnat and F.A. Chace (eds), Contributions on the Biology of the Gulf of Mexico. College Station, Texas A \& M University.

Pequegnat, L.H. and Williams, A.B. 1995. Two new species of Munidopsis (Decapoda, Anomura, Galatheidae) from the Western Atlantic Ocean. Journal of Crustacean Biology, 15: 786-792.

Schnabel, K.E. and Bruce, N.L. 2006. New records of Munidopsis (Crustacea: Anomura: Galatheidae) from New Zealand with description of two new species from a seamount and underwater canyon. Zootaxa, 1172: 49-67.

Váquez-Bader, A.R.; Gracia, A. and Lemaitre, R. 2014. A new species of Munidopsis Whiteaves, 1874 (Crustacea: Anomura: Galatheoidea: Munidopsidae) from the Gulf of Mexico and Caribbean Sea. Zootaxa, 3821: 354-362.

Whiteaves, J.F. 1874. On recent deep-sea dredging operations in the Gulf of St. Lawrence. American Journal of Science, (ser. 3) 7: 210-219.

Williams, A.B. and Van Dover, C.L. 1983. A new species of Munidopsis from submarine thermal vents of the east Pacific Rise at $21^{\circ} \mathrm{N}$ (Anomura: Galatheidae). Proceedings of the Biological Society of Washington, 96: 481-488.

WoRMS Editorial Board. 2014. World Register of Marine Species. Available from http://www. marinespecies.org at 